\title{
Task-based language teaching
}

\section{Abdel Kazeroni}

\section{OpenEdition}

\section{Journals}

Electronic version

URL: http://journals.openedition.org/asp/3750

DOI: 10.4000/asp.3750

ISSN: 2108-6354

\section{Publisher}

Groupe d'étude et de recherche en anglais de spécialité

\section{Printed version}

Date of publication: 1 December 1995

Number of pages: 113-132

ISSN: 1246-8185

\section{Electronic reference}

Abdel Kazeroni, «Task-based language teaching », ASp [Online], 7-10 | 1995, Online since 20

September 2013, connection on 30 April 2019. URL : http://journals.openedition.org/asp/3750 ; DOI

10.4000/asp.3750

This text was automatically generated on 30 April 2019.

Tous droits réservés 


\title{
Task-based language teaching
}

\author{
Abdel Kazeroni
}

1 The fundamental questions underlying the teaching and learning of second/foreign languages (L2), according to Galisson $(1985,1986)$ are as follows:

1. Why is an L2 taught/learnt? (educational values- and beliefs-system)

2. How is the L2 programme organised? (often referred to as syllabus or curriculum)

3. Who teaches? (teacher profile)

4. How is an L2 taught? (teaching methods and methodology)

5. Who learns? (learner profile)

6. How is an L2 learnt? (learning/acquisition research)

7. Where is an L2 learnt/taught? (instructed or uninstructed)

2 Long (1992) and Crookes (1993) adopt nearly identical views. Any L2 programme makes certain (tentative) assumptions regarding the above questions. These assumptions may be implicit or explicit. Any of the above points may act as the focus for L2 programme design. Whatever the centre of interest for the programme maker, designing an L2 programme involves constructing a syllabus. The syllabus determines what is to be taught and learnt. A teaching method has to be adopted in order to implement the syllabus. Any given teaching method has a particular conception of language teaching and language learning (Larsen-Freeman 1986; Richards \& Rodgers 1986; Germain 1993).

3 In the following sections, I will present two (Wilkins 1976; White 1988) different but similar ways of classifying L2 syllabuses. Then three different task-based syllabuses, which can be said to belong to the same syllabus type. Given that any syllabus has to be implemented through teaching (or activities prepared by a teacher), three different conceptions of L2 teaching (Freeman 1993; Richards 1993, 1994) are presented to pinpoint the rationale underlying any given approach to L2 teaching. In the penultimate section, SLA research on the "effectiveness" of formal L2 instruction and its implications for syllabus design and L2 teaching methodology are discussed. I will finally underline a few of the problems raised by task-based language teaching (TBLT) as suggested by SLA researchers. It must be pointed out at the outset that not all of the seven questions raised above are dealt with in this paper. 


\section{Syllabus Design}

There have traditionally been two different approaches to constructing syllabuses. One approach is based on determining discrete items (lexical items, grammar structures, communicative functions, etc.) to be learnt. The second attempts to determine how/for what purpose learners learn (L2 learning strategies and needs analysis) and then decide on the content. In other words there is a "whole chunk" approach to syllabus design. Wilkins (1976) refers to these approaches as synthetic and analytic respectively. In the former, the learner is expected to re-synthesize the discrete items, while in the latter the syllabus designer expects the learner to recognize linguistic regularities. As Wilkins puts it:

A synthetic language teaching strategy is one in which the different parts of language are taught separately and step- by-step so that acquisition is a process of gradual accumulation of the parts until the whole structure of the language has been built up. (Wilkins 1976: 2)

The learner is assigned a definite role and is expected to be patient:

The learner's task is to re-synthesize the language that has been broken down into a large number of smaller pieces with the aim of making his learning easier. ... It is only in the final stages of learning that the global language is reestablished in all its structural diversity. (Wilkins 1976: 2)

Analytic syllabuses, on the other hand,

are organized in terms of the purposes for which people are learning language and the kinds of language performance that are necessary to meet those purposes. (Wilkins 1976: 13)

In designing analytical syllabuses the learner, and not the syllabus designer, is expected to be analytic:

... since we are inviting the learner, directly or indirectly, to recognize the linguistic components of the language behaviour he is acquiring, we are in effect basing our approach on the learner's analytical capacities. (Wilkins 1976: 14)

White (1988) introduces Type A and Type B syllabuses. Type A syllabus deals with the WHAT of language learning and Type B syllabus with the HOW (see table 1).

Table 1

\begin{tabular}{|l|l|}
\hline Type A What is to be learnt? & Type B How is it to be learnt \\
\hline Interventionist & \\
\hline External to the learner & Internal to the learner \\
\hline Other directed & Inner directed or self fulfilling \\
\hline Determined by authority & Negotiated between learners and teachers \\
\hline Teacher as decision-maker & Learner and teacher as joint decision makers \\
\hline Content = what the subject is to the expert & Content = what the subject is to the learner \\
\hline
\end{tabular}




\begin{tabular}{|l|l|}
\hline $\begin{array}{l}\text { Content = a gift to the learner from the teacher } \\
\text { or knower }\end{array}$ & Content = what the learner brings and wants \\
\hline Objectives defined in advance & Objectives described afterwards \\
\hline Assessment by achievement or by mastery & $\begin{array}{l}\text { Assessment in relationship to learner's } \\
\text { criteria of success }\end{array}$ \\
\hline Doing things to the learner & Doing things for or with the learner \\
\hline
\end{tabular}

Reproduced from White 1988: 44-45

7 Both Wilkins' and White's definitions should be seen as a continuum and not as distinct oppositions. Syllabus design, it has been claimed, often takes place independently of teaching methodology:

A problem for applied linguists working on SL programme design is the tendency for developments in syllabus design and teaching methodology to occur independently of one another, and both independently of psycholinguistic research. (Long 1984: 94-95)

8 SLA research has, since the early 1980s, explored the relationships between the effects of certain types of formal language instruction and second language development. The studies carried out (Lightbown, Spada \& Wallace 1980; Lightbown, 1983; Long \& Porter 1985 - among others) have mostly observed activities that have become popular with the advent of the Communicative Approach. It is claimed (Ellis 1984, 1985; Long 1988) that formal language instruction has a positive effect on the rate and ultimate attainment of language learning if it provides opportunities for negotiation of meaning. During the same period SLA research has indicated that any instruction is constrained by learnability (Piennemen 1985, 1989, 1992). This latter point was meant to serve as guideline on syllabus design regardless of syllabus type and methodology employed for its implementation:

It is important to note in this context that SLA research is neutral towards the structural-versus-communicative dichotomy, because these main approaches to syllabus construction are not motivated on psycholinguistic grounds. (Pienneman 1989: 76)

Given that instruction was seen to play a positive role in L2 learning and the learnability hypothesis, some SLA researchers have proposed that there should be a shift of emphasis in syllabus design from Synthetic to Analytic type syllabuses. In fact Long \& Crookes (1993) extend Wilkins' definition of analytic syllabuses to include all those syllabuses that:

present the target language whole chunk at a time, in molar rather molecular units, without linguistic interference or control. They also rely on (a) the learners' presumed ability to perceive regularities in the input and include rules, and/or (b) the continued availability to learners of innate knowledge of linguistic universals and the ways language can vary, knowledge which can be reactivated by exposure to natural samples of the L2. Procedural, process and task syllabuses are examples of the analytic syllabus type. (Long \& Crookes 1993:11)

10 In the next section we will examine the different definitions of task and see why Long and Crookes argue in favour of task as the unit of analysis in syllabus design. 


\section{Task}

11 There is no general consensus with regards to the meaning and/or interpretation of “task". Definitions given of "task" vary greatly (Nunan 1989; Kumaravadivelu 1993). These definitions may encompass anything from tasks expected to take place outside the classroom to tasks specifically designed for the language classroom. There seem to be two broad rationales (Nunan 1989: 40) for tasks:

Table 2: Communicative classroom tasks

\begin{tabular}{|l|l|l|}
\hline Task type & Real-world & Pedagogic \\
\hline Rationale & Psycholinguistic & Rehearsal \\
\hline Reference & Needs analysis & SLA theory/research \\
\hline
\end{tabular}

Reproduced from Nunan 1989: 40

On closer scrutiny, both task types introduced by Nunan (1989) belong to the Analytic or Type B syllabus. However, one is interested in preparing learners for the world outside the classroom, and the other is concerned with the learners' "built-in" syllabus. The former probably recognising social accountability towards learners attends to their more immediate needs (otherwise the situation would be very similar to synthetic syllabuses), and the latter holding out that the route of acquisition remains unchanged regardless of type of instruction attends to the learners' psycholinguistic "readiness" for learning a given morpheme (SLA, having shown more interest in acquisition of morphemes so far leads one to assume that this would be its priority).

In what follows, different definitions of "task" will be presented. The list is in no way exhaustive.

Long (1985) takes "task" to be whatever one does in everyday life and defines it as:

a piece of work undertaken for oneself or for others, freely or for some reward. Thus, examples of tasks include painting a fence, dressing a child, filling out a form, buying a pair of shoes, making an airline reservation, borrowing a library book, taking a driving test, typing a letter, weighing a patient, sorting letters, taking a hotel reservation, writing a check, finding a street destination and helping someone across a road. In other words, by 'task' is meant the hundred and one things people do in everyday life, at work, at play, and in between. Tasks are the things people will tell you to do if you ask them and they are not applied linguists. (Long 1985: 89)

15 Crookes (1986) takes a similar position, however, extending his definition to include educational settings and defines task to be:

a piece of work or an activity, usually with a specified objective, undertaken as part of an educational course or at work. (Crookes 1986: 1, cited in Long \& Crookes 1993: 39)

Wright (1987) takes a more classroom-based position. For him tasks are:

...instructional questions which ask, demand or even invite learners (or teachers) to perform operations on input data. The data itself may be provided by teaching material or teachers or learners. I shall term this limited set of tasks "instructional tasks". (Wright 1987: 48) 
Krahnke (1987) and Prabhu (1987) focus their attention more directly at what goes on in the language classroom. Krahnke suggests that:

the defining characteristic of task-based content is that it uses activities that the learners have to do for noninstructional purposes outside of the classroom as opportunities for language learning. Tasks are distinct from other activities to the degree that they have noninstructional purposes. (Krahnke 1987: 67, cited in Kumaravadivelu 1993: 70-71)

17 And for Prabhu within the framework of the Banglore/Madras Communicational Teaching project:

An activity which required learners to arrive at an outcome from given information through some process of thought, and which allowed teachers to control and regulate that process, was regarded as a "task" (Prabhu 1987: 24)

18 For Breen (1987) "task" has a clear instructional role and the following definition is offered:

a broad sense to refer to any structural language learning endeavour which has a particular objective, appropriate content, a specified work procedure, and a range of outcomes for those who undertake the task. 'Task' is therefore assumed to refer to range of workplans which have the overall purpose of facilitating language learning - from the simple and brief exercise type to more complex and lengthy activities such as group problem-solving or simulations and decision-making. (Breen 1987: 23)

19 Candlin (1987) provides a learning-centred definition of task, which is probably the most complex and complete definition:

One of a set of differentiated, sequenceable, problem posing activities involving learners and teachers in some joint selection from a range of varied cognitive and communicative procedures applied to existing and new knowledge in the collective exploration and pursuance of foreseen or emergent goals within a social milieu. (Candlin 1987: 10)

Extending Candlin's definition and introducing genre, Swales (1990) takes a task to be:

one of a set of differentiated, sequenceable goal directed activities drawing upon a range of cognitive and communicative procedures relatable to the acquisition of pregenre and genre skills appropriate to a foreseen or emerging socio-rhetorical situation. (Swales 1990: 76)

21 Avoiding the complex variables introduced by Candlin and Swales, Nunan (1989) proposes the communicative task that he situates within the language classroom. He defines a communicative task to be:

a piece of classroom work which involves learners in comprehending, manipulating, producing or interacting in the target language while their attention is principally focused on meaning rather than form. (Nunan 1989: 10)

Richards, Platt and Weber (1985) also give a definition targeted at the classroom with implications for language use outside the classroom:

an activity or action which is carried out as the result of processing or understanding language (i.e., as a response). For example, drawing a map while listening to a tape, listening to an instruction and performing a command, may be referred to as tasks. Tasks may or may not involve the production of language. A task usually requires the teacher to specify what will be regarded as successful completion of the task. The use of a variety of different kinds of tasks in language teaching is said to make teaching more communicative ... since it provides a purpose for a classroom activity which goes beyond the practice of language for its own sake. (Richards, Platt \& Weber 1985: 289) 
can seen from the above definitions, "task" can mean anything. It can designate language-learning material developed to be used in the classroom, just as it can label whatever a living human being does. Language teaching approaches tend to be languagecentred, learner-centred, or language learning-centred (see Hutchinson \& Waters 1987). Tasks can be said to be learner-centred or language learning-centred. Task designers having distanced themselves from the tradition of using discrete linguistic forms as units of syllabus construction no longer take the language-centred approach. However, some SLA researchers now think that a task has to be accompanied with a focus on form, (Long \& Crookes 1992, 1993; Fotos \& Ellis 1991; Ellis 1992; Skehan 1993; Willis 1993). This implies that the language-centred approach has not completely been neglected. At this point one can ask two questions with regard to focus on form. Firstly, should focus on form follow or precede a given task? Secondly, how is focus on form organised? Some SLA researchers (Rutherford 1987; Fotos \& Ellis, 1991; Ellis 1992; Willis 1993) seem to favour Consciousness Raising with regard to the second question. However, the order of events seems far from being resolved. As Skehan (1993) puts it:

...there is a central ambivalence as to what comes first: the structure or the task. It is not argued here that tasks should clothe structures. On the other hand, it is unclear whether, within the constraints of attempting to control learners' attentional mechanisms, tasks can drive forward language development without any underlying system. At the moment, it is likely that task-based learning can proceed most effectively by a "loose focus" for the relationship between tasks and structures. As more is learned about naturalistic learning, it may be possible to be more exact about this relationship. (Skehan 1993: 24)

This extract from Skehan (1993) has three underlying messages. First of all, there is a need for focus on form, although we do not yet know how it is to be done. A loose focus may be the way forward (whatever that may mean). Secondly, the relationship between focus on form and language development is not clear. Finally, L2 instruction should be based on naturalistic learning. All these can be debated.

In fact, focus on form within the different approaches to task-based syllabus design remains a problem area as Table 3 shows. Table 3 summarizes three task-based syllabuses as discussed by Long and Crookes (1992, 1993): Procedural (Prabhu 1987); Process (Breen 1984, 1987; Candlin 1987); Task-Based Language Teaching (Long \& Crookes, 1992, 1993). Long and Crookes $(1992,1993)$ argue in favour of "task" as a unit of analysis for syllabus design because, as they see it, in this way one can construct a Type B syllabus whose merits they discuss at length (specially through attacking Type A syllabuses).

Table 3: Three types of Task-based syllabuses

\begin{tabular}{|l|l|l|l|}
\hline $\begin{array}{l}\text { Task- } \\
\text { based } \\
\text { syllabus }\end{array}$ & Procedural & Process TBLT syllabus & TBLT \\
\hline $\begin{array}{l}\text { Type of } \\
\text { task }\end{array}$ & $\begin{array}{l}\text { Language-learning centred. } \\
\text { Information gap, opinion } \\
\text { gap, and reasoning gap } \\
\text { activies. }\end{array}$ & $\begin{array}{l}\text { Learner-centred Social \& } \\
\text { problem-solving orientation. }\end{array}$ & $\begin{array}{l}\text { Language-learning } \\
\text { centred. Target tasks }\end{array}$ \\
\hline
\end{tabular}




\begin{tabular}{|c|c|c|c|}
\hline $\begin{array}{l}\text { Main } \\
\text { features }\end{array}$ & $\begin{array}{l}\text { Priority is given to task } \\
\text { completion meaning-based; } \\
\text { teacher speech resembles } \\
\text { "caretaker talk"; no } \\
\text { systematic correction of } \\
\text { learner errors; has been } \\
\text { subjected to rigorous } \\
\text { testing. }\end{array}$ & $\begin{array}{l}\text { Takes its roots in general } \\
\text { educational theory and } \\
\text { philosophy; centred on the } \\
\text { learner and learning as } \\
\text { opposed to language learner } \\
\text { and learning; learning is a } \\
\text { negociated process. }\end{array}$ & $\begin{array}{l}\text { Based on SLA and L2 } \\
\text { classroom research; } \\
\text { makes use of course } \\
\text { design for LSP; } \\
\text { relatively structured; } \\
\text { provides provision for } \\
\text { focus on form. }\end{array}$ \\
\hline $\begin{array}{l}\text { Potential } \\
\text { problem } \\
\text { areas }\end{array}$ & $\begin{array}{l}\text { No prior needs analysis, } \\
\text { hence no criteria/rationale } \\
\text { for task selection; arbitrary } \\
\text { grading and sequencing } \\
\text { selection; arbitrary grading } \\
\text { and sequencing of tasks; } \\
\text { lack of regard for a focus on } \\
\text { form as suggested by SLA } \\
\text { research. }\end{array}$ & $\begin{array}{l}\text { No prior needs analysis, } \\
\text { hence no criteria/rationale } \\
\text { for task selection; the } \\
\text { problem of grading and } \\
\text { sequencing of tasks is not } \\
\text { resolved; no explicit } \\
\text { provision is made for a focus } \\
\text { on form; no SLA rationale; } \\
\text { has not been subjected to } \\
\text { rigorous testing }\end{array}$ & $\begin{array}{l}\text { Limited research } \\
\text { base; the problem of } \\
\text { grading rand } \\
\text { sequencing of tasks is } \\
\text { not resolved; lesser } \\
\text { learner autonomy; } \\
\text { has not been } \\
\text { subjected to rigorous } \\
\text { testing. }\end{array}$ \\
\hline
\end{tabular}

Based on Long and Crookes (1992, 1993)

As table 3 indicates, the Procedural syllabus and TBLT are both driven by SLA research. The Procedural syllabus is basically meaning-based and although it does not share all the assumptions of the Monitor Theory (Krashen 1982), it does share the subconscious acquisition aspect of it (Prabhu 1987: 69-72). TBLT, on the other hand, takes its source in "non-Monitor Theory" SLA research which recognizes the positive effect of instruction on ultimate attainment and the rate of acquisition. The Process syllabus, concentrating on the learner as negotiator in classroom organisation of learning activities, tends to find inspiration in general learning theory and not language learning theory. An underlying assumption of the Process syllabus seems to be that what is planned (by an authority) is not necessarily what is taught or(/and) learnt, and therefore learners must be given responsibility for organization of learning activities. Given that these three approaches to task-based syllabus design have different task types, I will now examine how each of them constructs its syllabus.

Prabhu (1987) discusses various roles that may be assigned to a syllabus. Of immediate interest are the syllabus as an operational construct and the syllabus as an illuminative construct. The former defines possible procedures of teaching while the latter deals with the product of learning. He conceives the syllabus as an operational construct to be a direct aid to constructing suitable lesson plans and cumulative teacher knowledge. For Prabhu, within the framework of the Banglore/Madras project, the syllabus as an operational construct,

is concerned ... with what is to be done in the classroom, not necessarily what is perceived to be taught or learnt thereby; its role is essentially to make it possible for one teacher to draw on the experience of another - for many teachers to draw on the experience of some. A syllabus in this role was an immediate need for the teaching done on the project: those who taught early project classes made their experience available (in the form of a collection of tasks which they had found feasible and satisfying, in the sequence in which they had used them) to those who taught later classes at comparable levels of ability. This transmission of lesson plans 
from one teacher to another was in a very specific form, and the only step taken towards generalization was a descriptive or mnemonic labelling of different tasks and a listing of them in an order suggested both by experience and some reflection on it. The list was called a 'procedural syllabus', with the intention of indicating that it was only a specification of what might be done in the classroom - that is to say, only an operational construct. (Prabhu 1987: 86-87)

The operational construct can therefore be seen as a teacher's decision-making procedures and how a teacher arrives at a given decision for implementing a given task. With regard to syllabus as an illuminative construct Prabhu, having rejected grammatical content syllabuses, explains that:

A "content" syllabus may be said to be an illuminative construct which is also used as an operational construct, while a procedural syllabus is an operational construct which is deliberately different from illuminative constructs. A content syllabus is appropriate when the aim of teaching is an understanding by learners of the subject concerned, or when the development of an ability in learners is thought to be directly controllable in terms of the relevant illuminative construct. A procedural syllabus is justified when the ability to be developed is perceived as a matter of natural "organic" growth and teaching is directed to creating conditions which are most favourable to that process. (Prabhu 1987: 89-90)

Although the procedural syllabus is generally thought to be a Type B syllabus, one is struck by the fact that it does not entirely belong to this category. As far as assumptions about language learning are concerned (especially learning grammatical forms) one can say that it is Type B. However, when it comes to roles assigned to teachers as ultimate decision makers, it can be said to belong to Type A syllabuses. Organizing languagelearning experience is the responsibility of teachers. There does not seem to be any joint learner-teacher decision making. In fact to elucidate the major role that the teacher takes on, it is well worth noting how classroom activities were organized.

There were ... at least two parallel tasks in each lesson. The first, called perhaps misleadingly "pre-task", was to be attempted as a whole class activity, under the teacher's guidance and control. The second, called 'task' in contrast with the pretask, was to be attempted by each learner individually (or sometimes in voluntary collaboration with a fellow-learner) with assistance sought from the teacher when necessary on specific points. There was also a third component to each lesson, consisting of a quick marking of students' individual work (i.e. the outcome of the "task" stated by each student on paper). This marking was done, usually overnight, on the basis of content, not language, and was meant both to give students some feedback on their level of success and, equally, to give the teacher some idea of the level of challenge the task had presented. The teacher's assessment of the level of difficulty acted as input to the planning of subsequent lessons. (Prabhu 1987: 24)

Prabhu gives a list of the tasks that were attempted within the Banglore/Madras project (Prabhu 1987: 138-143). These tasks are of the type commonly used in teaching associated with the Communicative Approach (CA). The only difference is that in CA one ultimately concentrates on the language used, whereas the Procedural syllabus requires one to focus on outcome. The role played by the teacher in terms of classroom management and organization of activities (tasks themselves and whatever else that may take place in a classroom setting) is one that would usually be associated with a Type A syllabus. This also implies that the teacher has a lot of forward planning, on the spot decision-making, and whole-class activity organization to get on with. As can be seen, Long's and Crookes' $(1992,1993)$ classification of the Procedural syllabus within the Type B tradition does not totally hold together. They have overlooked the role of the teacher. They have merely 
contented themselves with the fact that the procedural syllabus does not use a grammar check-list as a means of syllabus design.

The Process syllabus rejecting the top-down approach to syllabus construction relies on learner participation in deciding what the next course of action should be. The design of a syllabus is an on-going activity. The teacher has to comply with the wishes of the learners and a lot of flexibility on her/his part is required. The syllabus is dynamic and can only be written once the L2 course is completed. Breen (1987) asks four main questions regarding task, for which he provides answers:

(i) WHY is the task being undertaken? (to practice the use of a rule, to deduce main ideas from a text, to share information, or to solve a particular problem, etc.); (ii) WHAT is the content of the task? (linguistic rules, functions of language, specialist subject-matter, everyday general knowledge, or practical skills and abilities for communicating or studying, etc.); (iii) HOW is the task to be done?(through recalling and transferring previously-learned information or skills, by a problem solving-process, by analysing data, or through the use of particular skills, etc.); (iv) WHERE is the task to be done?(in pairs or groups in classroom; in a class with direct teacher guidance; individually with self-access resources, such as a computer; outside a classroom in the wider community; or as homework, etc.) (Breen 1987: 25)

What is immediately striking with respect to Breen's view of learner participation is that one can label the Process syllabus as Type B but not necessarily as analytic. This is simply due to the fact that a group of learners may "opt" for a content syllabus and "traditional" teacher- fronted grammar teaching, and show preference for a synthetic syllabus. Although Long and Crookes $(1992,1993)$ correctly identify the Process syllabus as Type B (and it is probably the only one of this kind), they fail to underline that it can become synthetic through learner choice. What they term lack of needs analysis is due to the nature of Type B syllabuses. With regard to joint decision making one can say that although both teacher and learners are involved in deciding on what is to be done, one wonders how learners will really decide on how a task is to be implemented since, usually, the teacher is the only one trained to organize pedagogic activities. It is not entirely clear for what length of time learners would really actively participate in decision making. They may simply demand (specially in case of fee paying learners) that the teacher "did her/his job" and taught them the L2.

of the three types of task-based syllabus discussed by Long and Crookes $(1992,1993)$, they claim that only TBLT offers guidelines on syllabus construction (and they admit that there are still problem areas). A TBLT syllabus can be organized along the following guidelines (Long 1985):

1. Conduct a needs analysis to obtain an inventory of target tasks.

2. Classify the target tasks into task types.

3. From the task types, derive pedagogical tasks.

4. Select and sequence the pedagogical tasks to form a task syllabus. (Long 1985: 91)

To these one should add focus on form. They provide the following rationale for a focus on form:

If correct, Long's (1988) conclusions, [...] and other potential explanations of how instructed learners come to outperform naturalistic learners, support systematic provision for a focus on form in the design of language teaching. [...] [T]he same conclusions about the effects of instruction do not, however, support a return to a focus on forms (plural) in language teaching, that is, to the use of some kind of synthetic syllabus and/or a linguistically isolating teaching "method", such as ALfd, Silent Way, or TPR. (Long \& Crookes 1993: 38) 

Crookes actually break language down to discrete grammatical items that the word form appears in the singular? Do they regard language acquisition as a sequence of step by step form acquisition? If this is the case their TBLT syllabus is only partially Type $B$ and analytic. It should also be noted that "instruction" is never defined. (See Sheen 1994 for detailed discussion of this and other problems associated with the proposals of Long and Crookes 1992). With regard to task implementation, one only learns that:

TBLT is relatively "structured", in the sense of pre-planned and guided. (Long \& Crookes 1992: 42) 1993) may have overlooked three essential elements. Firstly, SLA is not only psycholinguistic research on morphology and syntax. Secondly, one cannot force a methodology on teachers through using "task" as a unit of analysis for syllabus design. Finally, given that a task has to be implemented, no mention is made of what is expected of the teacher in their "methodology". One can only assume that the teacher must carry out the so-called prior needs analysis, (and what happens if a learner changes jobs half way through an L2 course?). And how is the teacher to implement what appears to be L2 spoken in certain situations?

Given that the three task-based syllabuses assign a given role to the teacher -teacher as provider of comprehensible input, teacher as negotiator, teacher as organiser of tasks- I would like to examine them using the framework provided by Freeman and Richards (1993) and Richards (1994) in the next section.

\section{Conceptions of teaching}

41 Freeman and Richards (1993) and Richards (1994) identify three different conceptions of teaching that have been summarized in Table 4. What transpires from the study of the various task-based syllabuses is the role assigned to the teacher. Although Long and 
Crookes $(1992,1993)$ claim that the three task-based syllabuses are Type B, one cannot fail to see that in each case the teacher has to have a different conception of teaching or a mixture thereof.

Table 4: Conceptions of Teaching

\begin{tabular}{|c|c|c|}
\hline $\begin{array}{l}\text { Scientifically-based conceptions of } \\
\text { language teaching (based on } \\
\text { empirical research) }\end{array}$ & $\begin{array}{l}\text { Theory- and values-based } \\
\text { conceptions of language } \\
\text { teaching (based on } \\
\text { belief) }\end{array}$ & $\begin{array}{l}\text { Art/Craft conceptions of } \\
\text { language teaching }\end{array}$ \\
\hline $\begin{array}{l}\text { Teaching which is seen as an } \\
\text { operationalized learning }\end{array}$ & $\begin{array}{l}\text { Teaching based on theory, } \\
\text { i.e. systematic and } \\
\text { principled thinking, rather } \\
\text { than empirical } \\
\text { undertaking research }\end{array}$ & $\begin{array}{l}\text { Teaching } \\
\text { training, } \\
\text { individual } \\
\text { audiolingualism, etc. }\end{array}$ \\
\hline $\begin{array}{l}\text { Teaching which follows a tested } \\
\text { model identifying effective teacher } \\
\text { behaviours, such as questioning } \\
\text { movements for literature in the } \\
\text { curriculum, action research, etc. }\end{array}$ & $\begin{array}{l}\text { Teaching based on values, } \\
\text { appeals to educational or } \\
\text { social value systems for } \\
\text { justification }\end{array}$ & $\begin{array}{l}\text { Teacher's belief systems } \\
\text { Teachers' planning } \\
\text { decisions }\end{array}$ \\
\hline $\begin{array}{l}\text { Teaching which follows what } \\
\text { effective teachers do: especially used } \\
\text { in teacher training }\end{array}$ & & \\
\hline
\end{tabular}

Based on Freeman and Richards (1993) and Richards (1994)

At the beginning of the paper, seven questions were asked concerning an L2 programme. It seems that Long and Crookes fail to address the question of "who teaches". In fact through the use of the generic term "instruction" to refer to teaching methodologies they make the assumption that teacher is of little (or no?) relevance. There is currently a school of thought emerging that considers learning to be completely independent of teaching, and in some cases even denies that such a thing as teaching even exists (Narcy, personal communication, May 1994). Although it is true that some types of learning take place without having been exposed to teaching, the converse is not true, for any type of teaching will induce some form of learning. Stevick (1980) put this anecdotally:

There is an old story about a preacher in a revival meeting held in a big tent on the edge of town. When the time came to pass the collection plate, a man in the congregation stood up and shouted, "Hey, Brother! I thought you said salvation is as free as the rain that falls from the heavens! Then why are you asking us for money?" To which the preacher shot back, "Yes, Brother, salvation is as free as the rain that falls from the heavens! But you have to pay to have it piped to you. (Stevick 1980: 16)

\section{Task-based language teaching: problems}

Despite the attempt Long and Crookes $(1992,1993)$ make to integrate SLA into L2 syllabus design and teaching methodology through their introduction of TBLT, they fail in a number of ways. Of the seven parameters presented at the beginning of the paper, they 
only consider two. They only address the issues of syllabus design and SLA research. On these two issues they fail to give a complete picture of the events. It has been demonstrated that the three task-based syllabuses are not necessarily Type $B$, and that not all findings of SLA have been used to construct TBLT. Furthermore, we only have a limited knowledge of second/foreign language acquisition. Does this suffice to come up with a new approach to (not to say method of) language teaching? Because of a belief held in "task" as a unit of analysis in syllabus design, and the central role they accord to task in teaching and learning, they overlook the role of the teacher and learners as organisers (either together or independently).

The prior needs analysis to which they refer automatically excludes young learners as they may not know for what purpose they will be using their L2. As they ground their reasoning for identifying target tasks in Language for Specific Purposes it is worth mentioning Widdowson's (1983) educational distinction of English for Specific Purposes (ESP) and General Purpose English (GPE).

... ESP is essentially a training operation which seeks to provide learners with a restricted competence to enable them to cope with certain clearly defined tasks. These tasks constitute the specific purposes which the ESP course is designed to meet. The course, therefore, makes direct reference to eventual aims. GPE, on the other hand, is essentially an educational operation which seeks to provide learners with a general capacity to enable them to cope with undefined eventualities in the future. (Widdowson 1983: 6)

These are only some of the problems related to TBLT. However, what should be born in mind is that knowledge about one or two parameters involved in L2 programme design is not sufficient to come up with a new approach. Long and Crookes have completely overlooked, for instance, the multidimensional curriculum as proposed by Stern (1983, 1992) and Le Blanc (1989). The multidimensional curriculum in trying to bring together different parameters and through synthesizing what is known about each of them, resolves some of the problems posed by TBLT.

\section{BIBLIOGRAPHY}

Breen, M.P. 1984. "Process syllabuses for the language classroom”. In Brumfit, C.J. (ed.), General English Syllabus Design. ELT documents 118. Oxford: Pergamon Press Ltd., 47-60.

Breen, M.P. 1987. “Learner contributions to task design”. In Candlin, C.N. and D. Murphy (eds.), Language Learning Tasks. Lancaster Practical Papers in English Language Education, vol. 7. London: Prentice-Hall International (UK) Ltd and Lancaster University, 5-22.

Candlin, C.N. “Towards task-based language learning”. In Candlin, C.N. and D. Murphy (eds.), Language Learning Tasks. Lancaster Practical Papers in English Language Education, vol. 7. London: Prentice-Hall International (UK) Ltd and Lancaster University, 23-46.

Ellis, R. 1984. Classroom Second Language Development. Oxford: Pergamon Press.

Ellis, R. 1985. Understanding Second Language Acquisition. Oxford: Oxford University Press. 
Ellis, R. 1993. "The structural syllabus and second language acquisition”. TESOL Quarterly 27/1, 91-113.

Fotos, S. and R. Ellis. 1991. "Communicating about grammar: A task-based approach". TESOL Quarterly 25/4, 605-628.

Freeman, D. and J.C. Richards. 1993. "Conceptions of teaching and the education of second language teachers”. TESOL Quarterly 27/2, 193-216.

Galisson, R. 1985. "Éloge de la 'didactologie/didactique' des langues et des cultures (maternelles et étrangères) -D/DLC-”. Études de Linguistique Appliquée 64.

Galisson, R. 1986. “Didactologies et ideologies”. Étude de Linguistique Appliquée 60.

Germain, C. 1993. Évolution de l'enseignement des langues: 5000 ans d'histoire. Paris: CLE International. Krashen, S.D. 1982. Principles and Practice in Second Language Acquisition. Oxford: Pergamon Press.

Kumaravadivelu, B. 1993. "The name of the task and the task of naming: Methodological aspects of task-based pedagogy". In Crookes, G. \& S.M. Gass (eds.), Tasks in a Pedagogical Context Integrating Theory \& Practice. Clevedon: Multilingual Matters Ltd., 69-96.

Larsen-Freeman, D. 1986. Techniques and Principles in Language Teaching. Oxford: Oxford University Press.

Le Blanc, R. 1989. “Le curriculum multidimensionnel: une approche intégrée pour l'enseignement de la langue seconde”. Étude de Linguistique Appliquée 75, 78-94.

Lightbown, P.M. 1983. "Exploring relationships between developmental and instructional sequences in L2 acquisition". In Seliger, H.W. and M.H. Long (eds.), Classroom-oriented Research in Second Language Acquisition. Rowley, MA: Newbury House Publishers.

Lightbown, P.M., N. Spada and R. Wallace. 1980. "Some effects of instruction on child and adolescent ESL learners”. In Scarcella, R.C. and S.D. Krashen (eds.), Research in Second Language Acquisition. Rowley, MA: Newbury House Publishers, 162-172.

Long, M.H. 1985. “A Role for instruction in second language acquisition: Task-based language teaching”. In Hyltenstam, K. and M. Pienemann (eds.), Modelling and Assessing Second Language Acquisition. Clevedon: Multilingual Matters, 77-99.

Long, M.H. 1988. “Instructed interlanguage development”. In Beebe, L.M. (ed.), Issues in Second Language Acquisition: Multiple Perspectives. New York: Harper and Row, 115-141.

Long, M.H., \& G. Crookes. 1992. “Three approaches to task-based syllabus design”. TESOL Quarterly 26/1, 27-56.

Long, M.H. \& G. Crookes. 1993. "Units of analysis in syllabus design: The case for task". In Crookes, G. \& S.M. Gass (eds.), Tasks in a Pedagogical Context - Integrating Theory \& Practice. Clevedon: Multilingual Matters Ltd., 9-54.

Long, M.H. and P. A. Porter. 1985. "Group work, interlanguage talk, and second language acquisition”. TESOL Quarterly 19/2, 207-228.

Nunan, D. 1989. Designing Tasks for the Communicative Classroom. Cambridge: Cambridge University Press.

Pienemann, M. 1985. "Learnability and syllabus construction". In Hyltenstam, K. and M. Pienemann (eds.), Modelling and Assessing Second Language Acquisition. Clevedon: Multilingual Matters, 23-75. 
Pienemann, M. 1989. "Is language teachable? Psycholinguistic experiments and hypotheses". Applied Linguistics 10/1, 52-79.

Pienemann, M. 1992. Teachability Theory, Language Acquisition. Research Centre, The University of Sydney.

Prabhu, N.S. 1987. Second Language Pedagogy. Oxford: Oxford University Press.

Richards, J.C. 1994. "The sources of language teachers instructional decisions". Plenary address at the 1994 Georgetown University Round Table on Languages and Linguistics, Georgetown University, Washington, D.C., 13-16 March 1994.

Richards, J.C., J. Platt, J. and H. Weber. 1985. Longman Dictionary of Applied Linguistics. London: Longman.

Richards, J.C. \& T. Rodgers. 1986. Approaches and Methods in Language Teaching. Cambridge: Cambridge University Press.

Rutherford, W.E. 1987. Second Language Grammar: Learning and Teaching. London: Longman. Sheen, R. 1994. "A critical analysis of the advocacy of the task-based syllabus". TESOL Quarterly 28/1, 127-151.

Skehan, P. 1993. “A framework for the Implementation of Task-Based Learning”. In IATEFL 1993 Annual Conference Report, 17-25.

Stern, H.H. 1983. “Toward a multidimensional foreign language curriculum”. In Mead, (ed.), Foreign Languages: Key Links in the Chain of Learning. Middlebury, VT: Northeast Conference.

Stern, H.H. 1992. Issues and Options in Language Teaching. Oxford: Oxford University Press.

Stevick, E.W. 1980. Teaching Languages - A way and Ways. Boston, MA: Heinle \& Heinle Publishers.

White, R.V. 1988. The ELT Curriculum. Design. Innovation and Management. Oxford: Basil Blackwell.

Widdowson, H.G. 1983. Learning Purpose and Language Use. Oxford: Oxford University Press.

Widdowson, H.G. 1990. Aspects of Language Teaching. Oxford: Oxford University Press.

Willis, D. 1993. "Syllabus corpus and data-driven learning”. In IATEFL 1993 Annual Conference Report , 25-32.

Wilkins, D.A. 1976. Notional Syllabuses. Oxford: Oxford University Press.

Wright, T. 1987. "Instruction task and discoursal outcome in the L2 classroom". In Candlin, C.N. and D. Murphy (eds.), Language Learning Tasks. Lancaster Practical Papers in English Language Education, vol. 7. London: Prentice-Hall International (UK) Ltd and Lancaster University, 47-68.

\section{ABSTRACTS}

Task-Based Language Teaching (TBLT), it can be argued, is a derivative of the Communicative Approach (CA) and Second language Acquisition (SLA) studies. With reference to the current debate on language learning/language acquisition TBLT aims to demonstrate that certain types of communicative learning activities, if organised according to clearly-defined criteria, can lead to acquisition. However, there seem to be tasks designed to implement a CA attitude (Prahbu 1987); tasks based on what we know about language learning (Long 1985; Long \& Crookes 1992, 1993); and tasks based on what we know from general education theory (Breen 1984, 1987; Candlin 1987). In this paper we first examine two different types of syllabus, which seem to 
provide the rationale for TBLT. Then different types of task-based methods, and in particular categories of tasks as defined by Long \& Crookes $(1992,1993)$ are presented. We then see how the different task-based methods fit into the three conceptions of language teaching introduced by Freeman \& Richards (1993) and Richards (1994). The final section points out some of the problems associated with TBLT.

L'enseignement par tâches (ET) s'inscrit dans la mouvance des études sur l'approche communicative et l'acquisition d'une langue seconde. Dans le débat en cours sur l'apprentissage/ acquisition des langues, ET se veut la démonstration que certains types d'activités communicatives d'apprentissage peuvent mener à l'acquisition, si on les organise selon des critères bien définis. Cependant, il existe des tâches conçues pour la mise en œuvre d'une démarche communicative (Prahbu 1987); des tâches fondées sur ce que nous savons de l'apprentissage des langues (Long 1985 ; Long \& Crookes 1992, 1993); et des tâches fondées sur ce que nous connaissons grâce aux théories générales sur l'éducation (Breen 1984, 1987 ; Candlin 1987). Dans le présent article, nous examinons pour commencer deux types de programme d'étude qui semblent fournir une justification de ET. Nous présentons ensuite différents types de méthodes fondées sur la tâche à accomplir, notamment les catégories de tâches définies par Long \& Crookes $(1992,1993)$. Nous étudions de quelle manière ces méthodes s'insèrent dans les trois conceptions de l'enseignement des langues que proposent Freeman \& Richards (1993) et Richards (1994). Pour conclure, nous évoquons certains des problèmes que pose l'enseignement par tâches.

\section{INDEX}

Mots-clés: approche communicative, acquisition des langues, apprentissage, approche par les tâches

Keywords: communicative approach, learning, task-based language teaching

\section{AUTHOR}

\section{ABDEL KAZERON}

Abdel Kazeroni teaches at UTC Compiègne. 